\title{
Ability of taxonomic diversity indices to discriminate coastal lagoon environments based on macrophyte communities
}

\author{
David Mouillot $^{\mathrm{a}^{*}}$, Sylvain Gaillard ${ }^{\mathrm{a}}$, Catherine Aliaume ${ }^{\mathrm{a}}$, Marc Verlaque ${ }^{\mathrm{b}}$, Thomas Belsher ${ }^{\mathrm{c}}$, \\ Marc Troussellier ${ }^{a}$ and Thang Do $\mathrm{Chi}^{\mathrm{a}}$
}

\author{
aUMR CNRS-UMII 5119 Ecosystèmes Lagunaires, Université Montpellier II CC 093, 34095 Montpellier Cedex 5, \\ France \\ 'UMR 6540, Centre d'Océanologie de Marseille, Université de la Méditerranée, Parc scientifique et \\ Technologique de Luminy, F13288 Marseille Cedex 9, France \\ 'Ifremer, Station de Sète, Avenue Jean Monnet, BP 171-34203 Sète Cedex, France \\ *: Corresponding author : mouillot@univ-montp2.fr
}

\begin{abstract}
Lagoons are highly productive areas representing more than $50 \%$ of the coastline area in Languedoc-Roussillon (South of France, Mediterranean sea). These lagoons are very different in their environmental conditions, human influences, eutrophication levels and aquaculture intensity. Based on macrophyte communities associated with soft substrates, two indices of taxonomic diversity (the "average taxonomic distinctness" $\left(\Delta^{+}\right)$and the "variation in taxonomic distinctness" $\left(\Lambda^{+}\right)$) were used to discriminate four of these lagoons (Thau, Salse-Leucate, Bages-Sigean and Mauguio). Bages-Sigean presented a significant higher average taxonomic distinctness $(p<0.05)$ and Salse-Leucate had a significant higher variation in taxonomic distinctness $(p<0.05)$ without considering exotic species. The index values were neither influenced by sample size nor by presence of exotic species. Thus, the "average taxonomic distinctness" was related to human activities and eutrophication level whereas the "variation in taxonomic distinctness" was more related the environmental variability, associated with the prime stressor of salinity in brackish coastal lagoons.
\end{abstract}

Keywords: Biodiversity; Eutrophication; Human impact; Exotic species; Languedoc-Roussillon 


\section{Introduction}

Worldwide, lagoon systems represent $13 \%$ of the coastal line (Knoppers 1994) and with the other coastal ecosystems constitute a large part of the ecological richness of the biosphere (Costanza et al. 1997). Due to their location between the continent and the sea (interface area with freshwater inputs from the watershed and marine influence from the sea through the channel), and their shallow depths, lagoons are very productive ecosystems (on average of $300 \mathrm{~g} \mathrm{C} \mathrm{m}^{-2} \mathrm{y}^{-1}$, Knoppers 1994), but also very sensitive to both climatic and human activities. Lagoons are distributed all over the world coastline, but are not equally widespread on the different coastal areas. In the northwestern part of the Mediterranean Sea, lagoons are numerous. In the Languedoc-Roussillon area, they constitute $50 \%$ of the coastal line. They are subjected to many anthropogenic impacts, mainly due to permanent and seasonal population density increases, tourism activities expansion, aquaculture and agriculture. One of the urgent needs is to evaluate human influences on the structure and functioning of coastal lagoons, which was one of the goals of the "National Research Programme on Coastal Environment" (PNEC). In the context of this program, specific site studies were initiated in 1993 with a special interest in the macrophytic community, the composition and structure of which are known to be good indicators of environmental changes (Bachelet et al. 2000, Kunii \& Minamoto 2000, Sfriso et al. 2001). Moreover, numerous studies highlighted the functional impact of macrophytes on lagoon ecosystems by its effect on epifaunal assemblages (Parker et al. 2001), sediment microbial processes (Hansen et al. 2000), or on benthic fluxes of oxygen, sulphide and nutrients (Viaroli et al. 1996, Plante-Cuny et al. 1998, Dhargalkar \& Shaikh 2000).

To summarize a community composition, the more widely used parameter is the number of species or the specific diversity measured in samples ( $\alpha$-diversity) (Magurran 1988, Gaston 1996). However, this observed taxonomic richness is an underestimation of the true taxonomic richness (the real number of species living on the studied site) and the error involved will depend on sampling effort (Gaston 1996, Griffiths 1997). Furthermore, this specific diversity or richness is difficult to relate to the ecosystem productivity or disturbance because the diversity-productivity relationship remains controversial and is not always monotonic (Grace 1999, Waide et al. 1999, Mackey \& Currie 2001, Mittelbach et al. 2001). For these reasons, the community richness does not seem to be a useful indicator of disturbance in applied ecology (Drobner et al. 1998).

As early as 1949, Simpson suggested that the number of species only represented an aspect of species diversity, noting that the diversity of a given community also depends on the quantitative equilibrium between the species, which we term the evenness. To take into account the structure of the community, numerous diversity or evenness indices have been proposed such as the Shannon-Weaver (1949) index and its associated evenness or the Simpson (1949) index, for the most famous ones. These diversity indices are classically used in ecology to assess the environmental impacts on ecosystems (Coleman et al. 1997, Cusson \& Bourget 1997, McRae et al. 1998, Chiarucci et al. 1999, Weiher \& Keddy 1999, Pires et al. 2000). Nevertheless, some authors criticized the limited ability of these indices to discriminate between communities or to detect change within a given community (Cairns et al. 1993, Cao et al. 1996, Burel et al. 1998, Gray 2000, Lydy et al. 2000, Rice 2000). Moreover, 
these indices do not take into account functional or taxonomic differences between species whereas some authors pointed out the necessity of including these differences between species to assess diversity (Purvis \& Hector 2000, Shimatani 2001).

Since 1995, Warwick and Clarke $(1995,1998)$ and Clarke and Warwick $(1998,1999$, 2001) proposed four indices of taxonomic diversity that take into account the "weighted" taxonomic differences between species. The first two, termed taxonomic diversity $(\Delta)$ and taxonomic distinctness $\left(\Delta^{*}\right)$, are natural extensions of Simpson diversity and use abundance of species. The two last ones measure average and variation in taxonomic distinctness $\left(\Delta^{+}\right.$and $\Lambda^{+}$, respectively) with presence/absence data. Thus, the combination of the two last indices is supposed to provide a statistically robust summary of taxonomic relatedness patterns within an assemblage (Warwick \& Clarke 2001). These four indices are intended to be independent of sample size, unbiased, related to functional diversity and to environmental impact (Clarke \& Warwick 1998, Rogers et al. 1999, Clarke \& Warwick 2001, Warwick \& Clarke 2001, Warwick et al. 2002, Warwick \& Light 2002). Nevertheless, using $\Delta$ and $\Delta^{*}$, Somerfield et al. (1997) found no consistent pattern of decreasing taxonomic diversity of marine macrofaunal assemblages with increasing environmental impact and, following Hall \& Greenstreet (1998), indices incorporating taxonomic distinctness showed identical time trends to conventional diversity measures with fish communities.

Undeniably, these indices need further investigation concerning their ability to assess environmental impact. Moreover, they have not been widely used in ecology because one must know all the members of the community theoretically present on each site, and these methods are heavily dependent upon calculations, especially for the associated randomisation test.

In this study, we focus on the ability of two new weighted taxonomic diversity indices $\left(\Delta^{+}\right.$and $\left.\Lambda^{+}\right)$, based on presence/absence data, to discriminate coastal lagoon environments. To this aim, we use a database on macrophytic communities sampled in four coastal lagoons of the Languedoc-Roussillon (France, Mediterranean Sea) with high contrast in their environmental conditions such as eutrophication level. Then we discuss a lagoon classification based on taxonomic diversity of macrophytic communities.

\section{Material and methods}

\section{Study areas}

During the "National Research Program on Coastal Environment" (PNEC), four coastal lagoons located in the Languedoc-Roussillon area were sampled between 1998 and 1999: Bages-Sigean, Mauguio, Salse-Leucate and Thau Lagoon (Figure 1). Two of them, Salse-Leucate and Thau Lagoon, harbour shellfish aquaculture activities (mainly oyster aquaculture). As the breeding of oysters is not of a level to allow the collection of larva in the Mediterranean Sea, production is wholly dependent on the importation of adults or spat. Since 1961, professionals have imported Portuguese oysters and, from 1976, Japanese oysters (Crassostrea gigas). These importations caused numerous accidental marine species introductions. 
Main chemical and physical characteristics and the eutrophication level of each lagoon are summarized in Table 1 (RSL 2001). Eutrophication levels are estimated using parameters from the water column such as oxygen, turbidity, chlorophyll, pheopigments and some chemicals ( $\mathrm{P}, \mathrm{N}, \mathrm{NH}_{4}{ }^{+}$and $\mathrm{NO}_{2}{ }^{-} / \mathrm{NO}_{3}{ }^{-}$) (RSL 2001). Environmental features and human activities differ according to the lagoon:

Table 1. Environmental characteristics of the four studied lagoons. Mean values are given \pm standard deviation; organic matter is given as a percentage of dry sediment. Eutrophication level is estimated using parameters from the water column (RSL 2001) and varies between 1 (lowest eutrophication) and 5 (highest eutrophication).

\begin{tabular}{cccccc}
\hline Lagoon & Surface (ha) & Eutrophication level & Salinity (PSU) & Organic matter (\%) & Watershed surface (ha) \\
\hline Bages-Sigean & 3800 & 2 & $32.4( \pm 2.6)$ & $4( \pm 1.7)$ & 3800 \\
Mauguio & 3170 & 5 & $17.3( \pm 3.7)$ & $7.7( \pm 2)$ & 31300 \\
Salse-Leucate & 6500 & 1 & $33.8( \pm 1.5)$ & $5.4( \pm 4)$ & 3170 \\
Thau & 7000 & 2 & $35.3( \pm 0.7)$ & $7.2( \pm 4.8)$ & 35000 \\
\hline
\end{tabular}

- $\quad$ Bages-Sigean. This lagoon is the least influenced by human activities because of a low population density on the watershed. Water exchanges with the sea take place in the middle and south of the lagoon.

- $\quad$ Mauguio. All around this lagoon, human activities and urbanization have rapidly increased during the last thirty years because of development and the vicinity of the largest city of the region (Montpellier, 400000 inhabitants within agglomeration in 2001). Industrial and commercial buildings are built along this lagoon and agricultural activities occupy a part of the watershed. Communication with the sea takes place through a channel ("grau"), but several gates hamper the water exchanges, increasing eutrophication processes.

- $\quad$ Salse-Leucate. This lagoon is not highly impacted by human activities or by eutrophication. However, aquaculture activities are present (1000 tons of shellfish per year), and constitute an important source of accidental species introduction (RSL 2001, Sauriau 1991).

Thau lagoon. This lagoon is usually lightly impacted by eutrophication (RSL 2001) but it is the leading site of shellfish aquaculture in the Mediterranean Sea (about 15000 tonnes of shellfish of which 12-13 000 tonnes of oysters are produced per year). These activities influence the biochemical composition of the water column (Souchu et al. 2001). Thau lagoon is one of the major hot spots of accidental marine species introduction, especially of marine algae (Verlaque 2001). 
Figure 1. Lagoons location (Languedoc-Roussillon region, France)

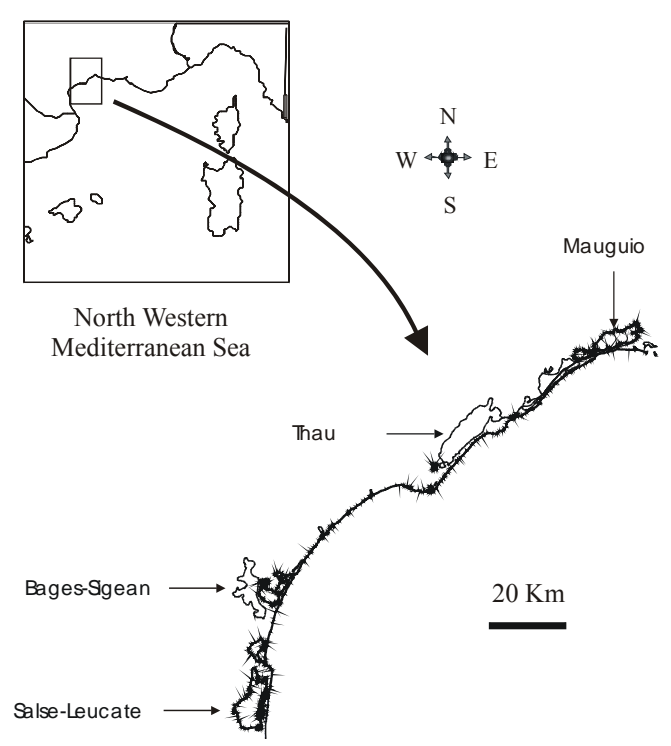

FGURE 1

\section{Sampling}

Macrophytic communities on soft substrates were sampled using a regular grid for each lagoon in the spring period depending on the studied community. Each sample represented a randomly distributed $2500 \mathrm{~cm}^{2}$ to $1 \mathrm{~m}^{2}$ quadrat in which the macrophytes were sampled by hand. Material was directly analysed or preserved in 4 $\%$ Formalin/seawater before identification to the laboratory. The number of quadrats was proportional to the surface area of the lagoon and we obtained respectively 57, 52, 32 and 32 samples for Thau, Salse-Leucate, Bages-Sigean and Mauguio lagoons.

A bibliographical analysis on the four Languedoc-Roussillon lagoons yielded 202 species of aquatic macrophytes, of which 43 are introduced (Verlaque 2000, 2001) (see Appendix). These 202 species were assumed to represent the list of species potentially present in the region. The hierarchical tree was constructed partially based on the taxonomic classification found in the world-wide web electronic publication: http://www.algaebase.com/ (Guiry \& Nic Dhonncha 2003).

\section{Taxonomic diversity indices}

The first diversity index based on the taxonomic relationship between species proposed by Warwick and Clarke (1995), the taxonomic diversity index $(\Delta)$, can be 
seen as a generalization of the Simpson diversity index incorporating an element of taxonomic relatedness whereas the second is a measure of taxonomic distinctness $\left(\Delta^{*}\right)$. Both can include abundances of species.

When data are only presence/absence of species, $\Delta$ and $\Delta^{*}$ converge to the average taxonomic distinctness $\left(\Delta^{+}\right)$(Clarke \& Warwick 1998, Warwick \& Clarke 2001) with the formula:

$$
\Delta^{+}=2 \frac{\sum \sum_{i<j} \omega_{i j}}{S(S-1)}
$$

where $S$ is the species richness and $\omega_{i j}$ is the " distinctness weight " given to the path length linking species $i$ and $j$ in the hierarchical classification.

Recently, Clarke and Warwick (2001) proposed a new index based on the evenness of the distribution of taxa across the hierarchical taxonomic tree. This "variation in taxonomic distinctness" can be expressed by:

$$
\Lambda^{+}=2 \frac{\sum \sum_{i<j}\left(\omega_{i j}-\bar{\omega}\right)^{2}}{S(S-1)}=2 \frac{\sum \sum_{i<j} \omega_{i j}^{2}}{S(S-1)}-\bar{\omega}^{2} \quad \text { where } \bar{\omega}=2 \frac{\sum \sum_{i<j} \omega_{i j}}{S(S-1)}
$$

When species are placed within a taxonomic hierarchy, based on the Linnean classification into phylum, class, order, family, genus and species (Appendix), the average taxonomic distinctness, $\Delta^{+}$, is simply the mean number of steps up the hierarchy that must be taken to reach a taxonomic rank common to two species, computed across all possible pairs of species in an assemblage (Clarke \& Warwick 1998, 1999, Warwick \& Clarke 2001). Thus, if two species are congeneric, one step (species-to-genus) is necessary to reach a common node in the taxonomic tree; if the two species belong to different genera but the same family, two steps will be necessary (species-to-genus, and genus-to-family); and so on, with these numbers of steps averaged across all species pairs. Step lengths are standardized so that the distinctness of two species connected at the highest taxonomic level is set equal to 100 (Clarke \& Warwick 1999); $\Delta^{+}$being between 0 and 100 and $\Lambda^{+}$being positive. If $\Delta^{+}$is the mean path length through the taxonomic tree connecting each pair of species, $\Lambda^{+}$is simply the variance of these pairwise path lengths and could be seen as an index of the "complexity" of the hierarchical tree.

These two last indices $\Delta^{+}$and $\Lambda^{+}$, used in our study, are explained in more detail in the synthesis of Warwick and Clarke (2001) and in Figure 2. 
Figure 2. Two theoretical trees ( $a$ and $b$ ) with the same richness ( 7 species) but with a different taxonomy. The mean path length between species is the same for the two trees and thus $\Delta^{+}$is identical. The tree structure has a greater unevenness or variability in (b) compared to (a), thus the variation in taxonomic distinctness $\left(\Lambda^{+}\right)$is higher for (b). According to Clarke $\&$ Warwick (2001), the « distinctness weight » given to the path length between each taxonomic level is 33.33 with a total of 4 levels.

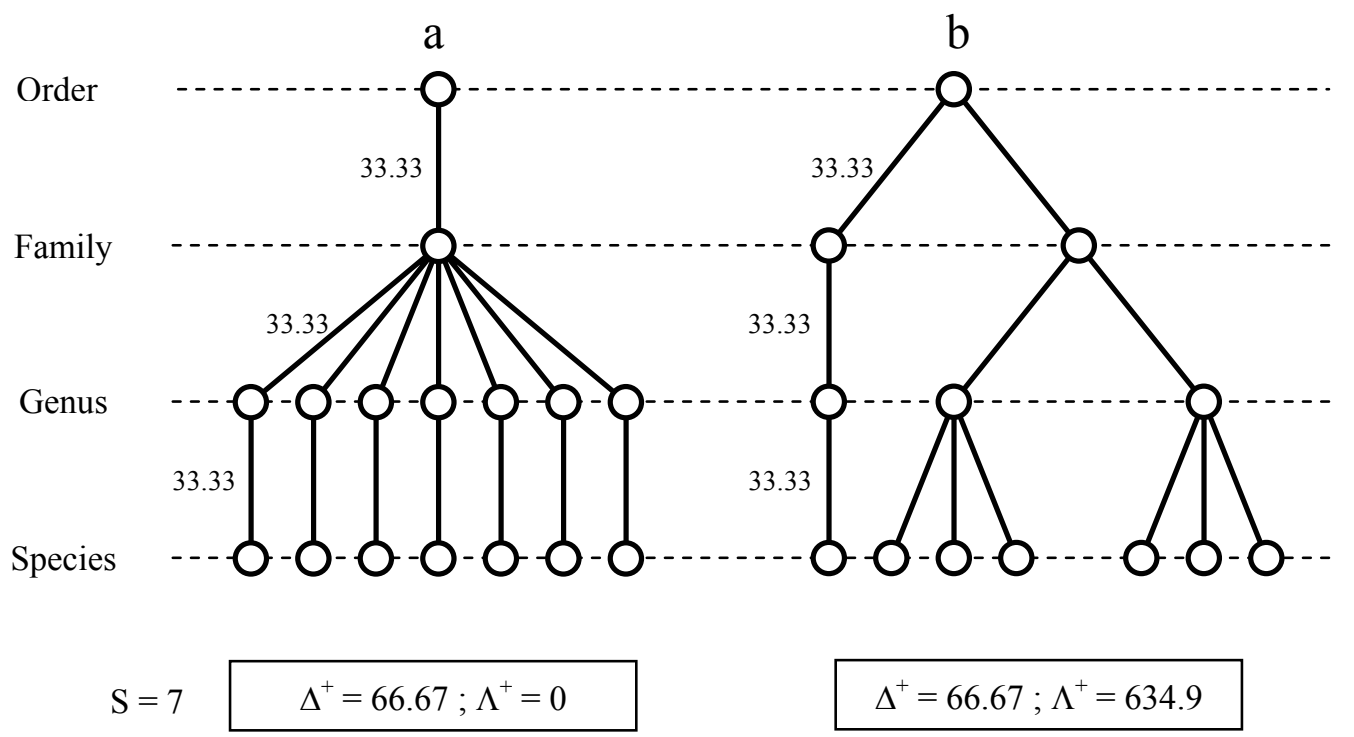

\section{Estimation and randomisation tests}

Warwick and Clarke (1998) developed a method to test each index based on the deviance from the null hypothesis: deviance between the index obtained for one locality and that calculated from the whole flora, i.e., for the present study, samples from one lagoon are regarded as random samples from the whole LanguedocRoussillon macrophytic flora. To test the null hypothesis, we selected randomly from the species list (202 species), 10000 subsamples of a fixed number of species. We estimated both indices $\Delta^{+}$and $\Lambda^{+}$on each subsample to obtain a distribution of 10 000 index values for each richness level between 10 and 200 species with a regular increase of 10 species. Then, we constructed a "funnel" representing the $95 \%$ confidence intervals for the null hypothesis. We compared the observed indices to these distributions to obtain a $p$ value to reject or accept the null hypothesis. If the species list established for one lagoon is assumed to be a random sample of the total species list, indices should fall within the confidence funnel (with $5 \%$ type I error).

For 200000 simulated communities (10 000 simulated replicates x 20 sample sizes) and for each lagoon community, we calculated $\Delta^{+}$and $\Lambda^{+}$using a computer program developed using borland $\mathrm{C}++$ Builder 5.0. To use this program, the complete hierarchical tree for each lagoon must be known from the species to the reign level. 


\section{Results}

Species richness of soft substrate macrophytic communities is respectively $41,23,8$ and 7 for Thau, Salse-Leucate, Bages-Sigean and Mauguio Lagoons. 15 species for Thau, 3 for Salse-Leucate and 1 for Bages-Sigean are exotic taxa from Asia (Appendix).

Taxonomic diversity indices are given in Table 2 for each lagoon, for the whole species list and for only exotic species or non-exotic species of this list. The $95 \%$ confidence funnel was constructed for $\Delta^{+}$(Figure 3 ). We can notice that Thau, SalseLeucate and Mauguio lagoons show no departure from the expected $\Delta^{+}$under the null hypothesis, i.e., each lagoon is a random subsample of the whole macrophytic flora. Bages-Sigean presents a significant higher average taxonomic distinctness $(p<0.05)$. Even though few species were observed (8), 4 different phyla with 2 species each were represented in this lagoon (see Appendix): Magnioliophyta (Zostera marina and

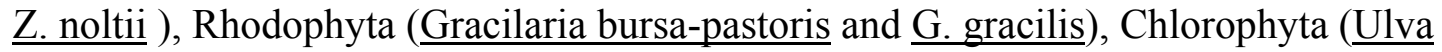
rigida and Cladophora sp.) and Heterokontophyta (Sargassum muticum and Cladostephus spongiosus). This pattern suggests high path length between species

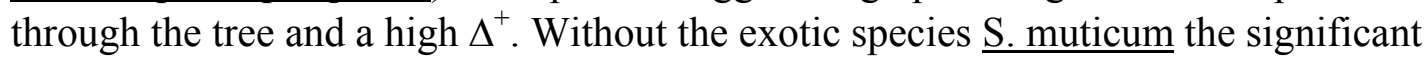
higher average taxonomic distinctness for Bages-Sigean lagoon disappears. The lowest $\Delta^{+}$value is obtained for Mauguio lagoon with only two phyla, two families having 4 species (total of 7) leading to one relative low path length between species (Table 2, Fig. 2 and Appendix).

Figure 3. Values of the Average Taxonomic Diversity $\left(\Delta^{+}\right)$for the macrophyte communities in Thau, Salse-Leucate, Bages-Sigean and Mauguio lagoons, plotted against the number of species on the $95 \%$ confidence funnel (see Estimation and randomisation test). Triangles, circles, squares and diamonds are for Thau, Salse-Leucate, Bages-Sigean and Mauguio lagoons, open marks are for macrophyte communities without exotic species, respectively.

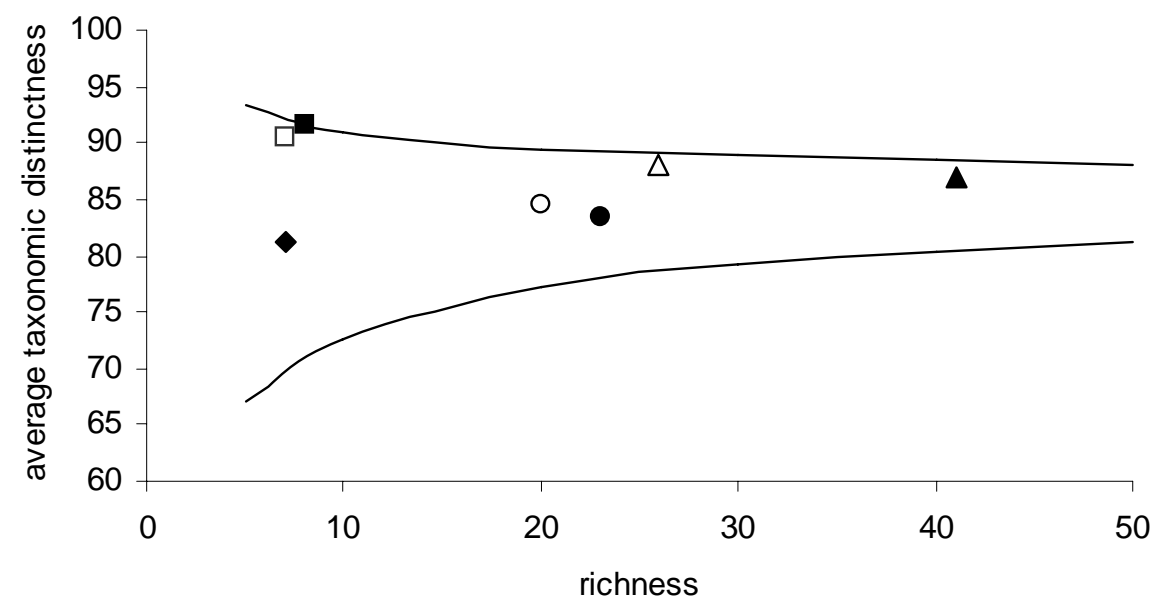


Results for $\Lambda^{+}$are shown in Fig. 4 and Table 2. Thau, Bages-Sigean, Mauguio and Salse-Leucate lagoon show no significant values for variation in taxonomic distinctness $(p>0.05)$. If exotic species are removed from Salse-Leucate, BagesSigean and Thau lagoons, $\Lambda^{+}$remains not significant for Thau and Bages-Sigean lagoons whereas $\Lambda^{+}$becomes significant for Salse-Leucate (Table 2). For this last lagoon 9 out of 12 orders sampled have only one species and, at the same time, 3 families (Cladophoraceae, Ceramiaceae, Rhodomelaceae) represent 11 species (about half of the total) leading to a high variation in the taxonomic tree (see Appendix).

Figure 4. Values of the Variation in Taxonomic Diversity $\left(\Lambda^{+}\right)$for the macrophyte communities in Thau, Salse-Leucate, Bages-Sigean and Mauguio lagoons, plotted against the number of species on the $95 \%$ confidence funnel (see Estimation and randomisation test). Triangles, circles, squares and diamonds are for Thau, Salse-Leucate, Bages-Sigean and Mauguio lagoons, open marks are for macrophyte communities without exotic species, respectively.

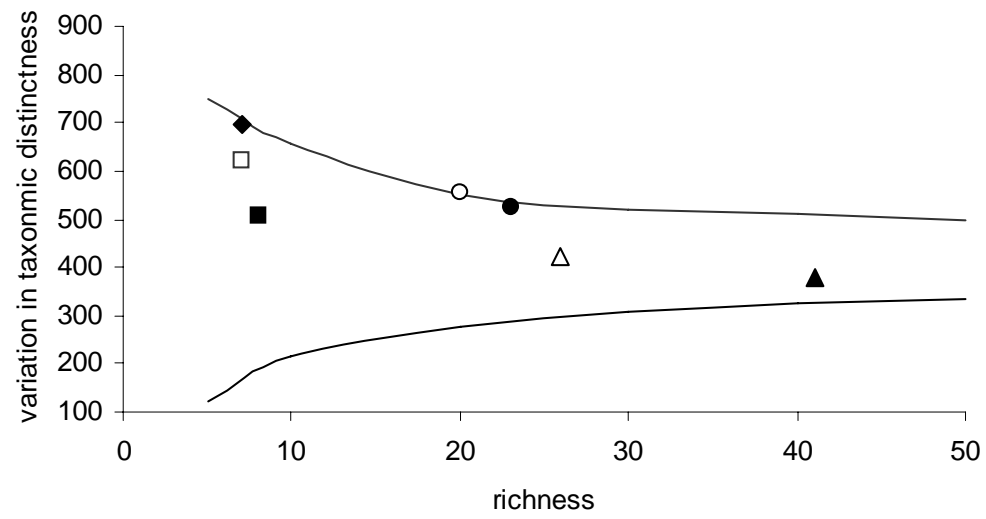




\section{Discussion}

First of all, by simulating various sample sizes or species richness from the whole species list, we can assess whether both indices are independent of sample size (Figs 3-4) as indicated by the authors in previous studies (Clarke \& Warwick 1998, Warwick \& Clarke 2001). When diversity indices are used to assess impact on communities, the major problems are the dependence on sample size (number of species sampled) and the ability to detect environmental influences. For the usual diversity indices and species richness, the relationship between diversity values and sample size was emphasized in the literature (Rice 2000). This kind of relation prevents any comparison between communities with different species richness. This is not the case with the indices used in the present paper.

Secondly, it appears that taxonomic diversity indices are weakly influenced by the presence of exotic species. Indeed, values of these indices vary little whether we consider the presence of exotic species, of non-exotic species or both (Table 2). This result is surprising because exotic species are supposed to add taxonomic diversity with new phyla, but the taxonomic diversity of macrophyte assemblages seems very robust. For example, Thau has been shown to be a "hot spot" for the accidental introduction of exotic species because of aquaculture activities (Verlaque 2001). In this lagoon, the 15 exotic species present in the samples add 5 new families (Rhodymeniaceae, Areschougiaceae, Dasyaceae, Chordaceae, Monostromataceae) and one new order (Laminariales), but the taxonomic index and the variance are not significantly different from the null hypothesis for this lagoon. This result could be related to the index values for the whole community of macrophytes in LanguedocRoussillon lagoons. When we consider only exotic species or only non-exotic species in Table 2, we observe that $\Delta^{+}$and $\Lambda^{+}$are very similar to the whole community values. For the Salse-Leucate lagoon, we have the same evidence: $\Lambda^{+}$is not positively influenced by exotic species (Fig. 4). This result is in total accordance with the study of Enquist et al. (2002) suggesting that the processes which structure the taxonomic diversity of woody plant communities, operate in a regular manner over millions of years and across broad geographical gradients. Diversity might be more strongly regulated by local ecological and evolutionary rules, and only weakly influenced by environmental or historical factors such as dispersal barriers or speciation (Gotelli 2002). In other words, the taxonomic diversity or the structure of the taxonomic tree is about the same for exotic or non-exotic species (results for the whole community in table 2).

In many studies, diversity indices failed to assess environmental impact. For example Cao et al. (1996), Karydis and Tsirtsis (1996) or Lydy et al. (2000) showed the inefficiency of diversity indices in detecting polluted communities. According to Danilov and Ekelund (1999), all of the diversity indices calculated (Hurlbert's, Margalefs, Menhinick's, Shannon's, Simpson's, McNaughton's and Species Number) failed to distinguish between different levels of eutrophication. Likewise, Fortin et al. (1999) were unable to discriminate between post-fire successional gradient sites using only Simpson and Shannon diversity indices. Using taxonomic diversity as indicators, Somerfield et al. (1997) did not detect any influence of pollution impact when these indices are supposed to assess environmental changes (Warwick \& Clarke 1998, Rogers et al. 1999). In the present study, even if the four lagoons considered are very different in their environmental conditions, we observed only 
two weak significant results, i.e. departure from the null hypothesis (table 2). We observe a narrow range for $\Delta^{+}$values (81.11-91.67) and a range of 378.10-698.77 for $\Lambda^{+}$values.

Mauguio lagoon, the most depressed one in our study, presents the lowest $\Delta^{+}$value (81.11) whereas the highest $\Delta^{+}$value was observed for the less human impacted lagoon (low eutrophication, no aquaculture, low agriculture activity and low population density on the watershed) (table 1). A significant highest $\Delta^{+}$value for Bages-Sigean suggests large ecological niches are available with low environmental stress allowing macrophyte species with a high taxonomic diversity and different biological requirements to be established. For example, we found two Heterokontophyta species in Bages-Sigean (Sargassum miticum and Cladostephus spongiosus) whereas this phylum is absent from Salse-Leucate and Mauguio lagoons (appendix). We noted the presence of Sargassum muticum in Bages-Sigean lagoon, which is an invasive species in Europe (Rueness 1989), where no aquaculture activity is present. In contrast, we can hypothesize that environmental constraints in the Mauguio lagoon limit the taxonomic diversity of macrophyte community. For example, more than half of the species are from two families (Gracilariaceae and Ulvaceae) with species able to live in such impacted environments. Salse-Leucate and Thau lagoons with low eutrophication level but human impact through aquaculture (Souchu et al. 2001) were not discriminated from the regional pool with medium $\Delta^{+}$values.

The only significant result for $\Lambda^{+}$was obtained for the Salse-Leucate macrophyte community when exotic species were not considered. In this case the taxonomic tree is more irregular than the ones obtained under the null model. The highest level of $\Delta^{+}$ , i.e. the most irregular observed taxonomic tree, was found for Maugio lagoon (Figure 4, table 2) which had the highest eutrophication level and the lowest salinity level compared to the other three lagoons considered (Table 1). Nevertheless this trend was not observed when we consider the four lagoons of the study. More sampled lagoons are thus necessary to recommend $\Lambda^{+}$as a good indicator for the eutrophication level. $\Lambda^{+}$seems more related to the salinity coefficient of variation (ratio of the standard deviation to the mean) in our study. This coefficient varies from $2 \%$ for Thau lagoon to $21 \%$ for Maugio with medium values for Bages-Sigean ( 8 $\%)$ and Salse-Leucate $(4.5 \%)$ lagoons. The relationship between the salinity coefficient of variation (environmental variability) and $\Lambda^{+}$is significant and positive $(p<0.05)$. The distribution of organisms and diversity within estuaries had already been supposed to be influenced more highly by variation than by absolute salinity regimes (Attrill 2002). The environmental variability, associated with the prime stressor of salinity in brackish coastal lagoons, would therefore seem to influence the variation in taxonomic distinctness of macrophyte communities. We summarize all these tendencies in Figure 5 and speculate about a classification for coastal lagoon environments based on macrophyte communities, a classification independent of sample size, species richness or exotic invasion. We need certainly more lagoons to validate this classification more particularly those with high environmental variability but low human impact. 
Table 2. Taxonomic diversity indices and species richness for the whole potential community of macrophytes (regional pool) in Languedoc-Roussillon lagoons and for the four sampled lagoons. When one index is significantly higher (5\% type I error) than expected (null hypothesis of random sample in the whole community) the sign + is added.

\begin{tabular}{|c|c|c|c|c|}
\hline community & species considered & number of species & $\begin{array}{c}\text { average taxonomic distinctness } \\
\qquad \Delta^{+}\end{array}$ & $\begin{array}{l}\text { variation in taxonomic distinctness } \\
\qquad \Lambda^{+}\end{array}$ \\
\hline \multirow{3}{*}{ Regional pool } & all & 202 & 85.10 & 408.97 \\
\hline & exotic & 43 & 82.37 & 445.66 \\
\hline & without exotic & 159 & 85.74 & 409.51 \\
\hline \multirow{2}{*}{ Thau } & all & 41 & 87.05 & 378.10 \\
\hline & without exotic & 26 & 88.15 & 421.21 \\
\hline \multirow{2}{*}{ Salse-Leucate } & all & 23 & 83.4 & 525.91 \\
\hline & without exotic & 20 & 84.56 & $556.97(+)$ \\
\hline \multirow{2}{*}{ Bages-Sigean } & all & 8 & $91.67(+)$ & 505.95 \\
\hline & without exotic & 7 & 90.48 & 623.58 \\
\hline Mauguio & all & 7 & 81.11 & 698.77 \\
\hline
\end{tabular}

Research on summarizing information from a community is still useful in applied ecology, even if "biodiversity can never be fully captured by a single number" (Purvis \& Hector 2000). Here, we applied for the first time, two new taxonomic indices based on presence/absence data to macrophyte communities sampled from four Mediterranean lagoons. A significant highest average taxonomic distinctness was estimated for the less human impacted lagoon (low eutrophication and no aquaculture) whereas other lagoons were not discriminated from the regional pool. Thus, proposing diversity indices that include differences between species is certainly an important step in ecology. These differences could be estimated through genetic data to obtain a phylogenetic diversity (Clarke \& Warwick 2001) but interpretation of these differences is still unclear. These differences could be functional. Recently, Petchey and Gaston (2002) used a new functional diversity estimation based on morphological characters of species. We can expect some advances on this topic because functional diversity indices could be more relevant in environmental impact assessment or in ecosystem functioning studies.

\section{Acknowledgments}

This study was granted by Thema-based Research Project \# 4 "Numerical methods to study the influence of hydroclimatic/anthropic factors on the spatio-temporal variability of coastal ecosystems" (coordinators B Beliaeff and JP Durbec) from the "National Research Programme on Coastal Environment" (PNEC). We would like to thank JM Deslous-Paoli for his participation in diving operations and fieldwork and the Station of IFREMER (Sète) for the facilities provided during the fieldwork. We wish to thank BJ Anderson, N Mason, JB Wilson and an anonymous reviewer for helpful comments and language corrections. 
Figure 5. Classification of Languedoc-Roussillon lagoons based on taxonomic diversity indices. Environmental variability is related to the variation of environmental factors such as salinity or temperature.

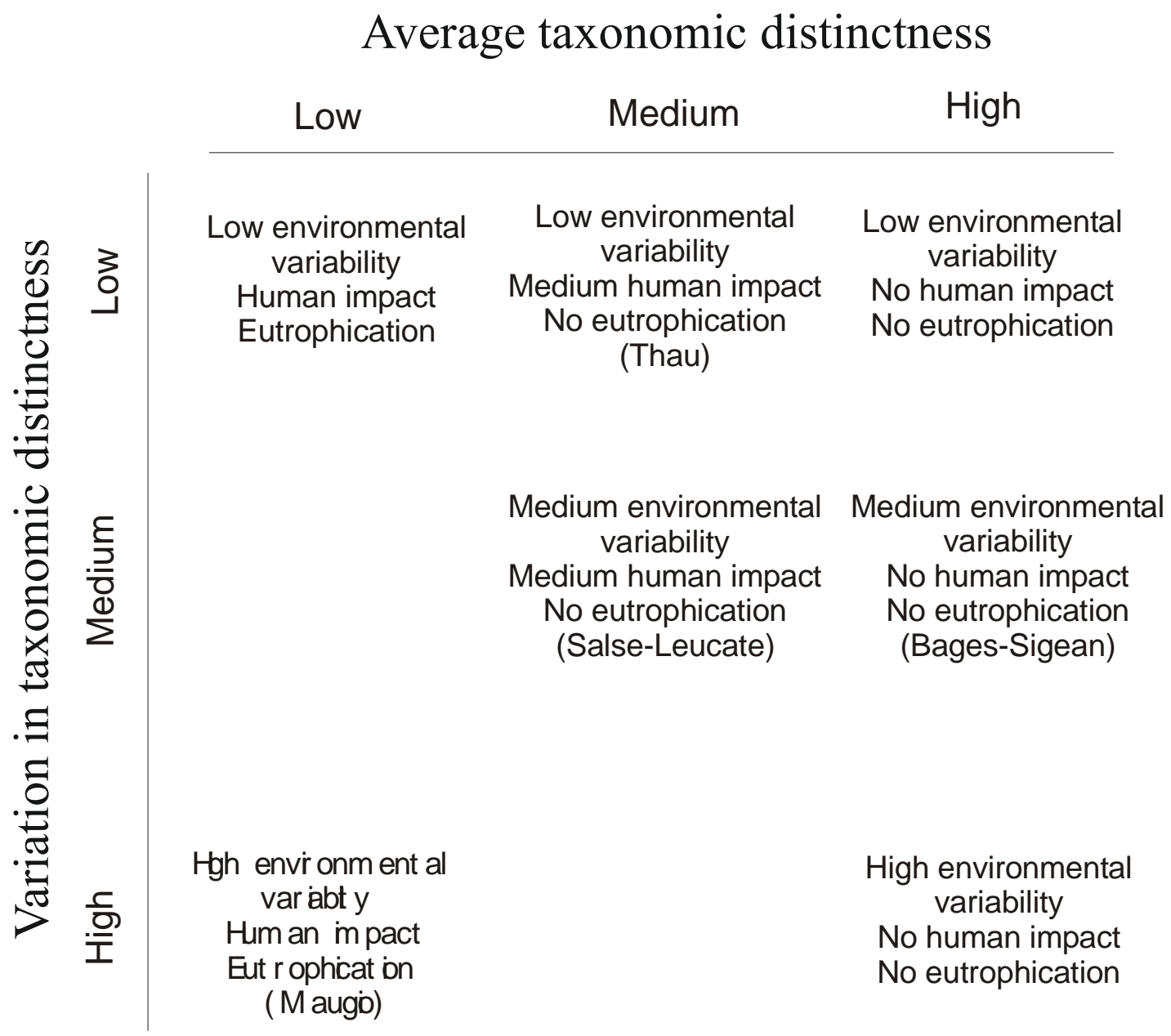




\section{References}

Attrill, M.J., 2002. A testable linear model for diversity trends in estuaries. Journal of Animal Ecology 71, 262-269.

Bachelet, G., de Montaudouin, X., Auby, I. and Labourg, P.J., 2000. Seasonal changes in macrophyte and macrozoobenthos assemblages in three coastal lagoons under varying degrees of eutrophication. Ices Journal of Marine Science 57, 1495-1506.

Burel, F., Baudry, J., Butet, A., Clergeau, P., Delettre, Y., Le Coeur, D., Dubs, F., Morvan, N., Paillat, G., Petit, S., Thenail, C., Brunel, E. and Lefeuvre, J.C., 1998. Comparative biodiversity along a gradient of agricultural landscapes. Acta Oecologica 19, 47-60.

Cairns, J.J. and Pratt, J.R., 1993. A history of biological monitoring using benthic macroinvertebrates. In, Freshwater biomonitoring and benthic macroinvertebrates, eds. Rosenberg, D.M., Resh, V.H., pp 10-27. Chapman and Hall, New York.

Cao, Y., Bark, A.W. and Williams, W.P., 1996. Measuring the responses of macroinvertebrate communities to water pollution, a comparison of multivariate approaches, biotic and diversity indices. Hydrobiologia 341, 1-19.

Chiarucci, A., Wilson, J.B., Anderson, B.J. and DeDominicis, V., 1999. Cover versus biomass as an estimate of species abundance, does it make a difference to the conclusions? Journal of Vegetation Science 10, 35-42.

Clarke, K.R. and Warwick, R.M., 1998. A taxonomic distinctness index and its statistical properties. Journal of Applied Ecology 35, 523-531.

Clarke, K.R. and Warwick, R.M., 1999. The taxonomic distinctness measure of biodiversity, weighting of step lengths between hierarchical levels. Marine Ecology Progress Series 184, 21-29.

Clarke, K.R. and Warwick, R.M., 2001. A further biodiversity index applicable to species lists, variation in taxonomic distinctness. Marine Ecology Progress Series 216, 265278.

Coleman, N., Gason, A.S.H. and Poore, G.C.B., 1997. High species richness in the shallow marine waters of south-east Australia. Marine Ecology Progress Series 154, 17-26.

Costanza, R., Darge, R., Degroot, R., Farber, S., Grasso, M., Hannon, B., Limburg, K., Naeem, S., Oneill, R.V., Paruelo, J., Raskin, R.G., Sutton, P. and Vandenbelt, M., 1997. The value of the worlds ecosystem services and natural capital. Nature 387, 253-260.

Cusson, M. and Bourget, E., 1997. Influence of topographic heterogeneity and spatial scales on the structure of the neighbouring intertidal endobenthic macrofaunal community. Marine Ecology Progress Series 150, 181-193.

Danilov, R. and Ekelund, N.G.A., 1999. The efficiency of seven diversity and one similarity indices based on phytoplankton data for assessing the level of eutrophication in lakes in central Sweden. Science of the Total Environment 234, 15-23.

Dhargalkar, V.K. and Shaikh, N., 2000. Primary productivity of marine macrophytes in the coral reef lagoon of the Kadmat Island, Lakshadweep. Current Science 79, 11011104.

Drobner, U., Bibby, J., Smith, B. and Wilson, J.B., 1998. The relation between community biomass and evenness, what does community theory predict, and can these predictions be tested? Oikos 82, 295-302.

Enquist, B.J., Haskell, J.P. and Tiffney, B.H., 2002. General patterns of taxonomic and biomass partitioning in extant and fossil plant communities. Nature 419, 610-613.

Fortin, M.J., Payette, S. and Marineau, K., 1999. Spatial vegetation diversity index along a postfire successional gradient in the northern boreal forest. Ecoscience 6, 204-213.

Gaston, K.J., 1996. Biodiversity. Blackwell, Oxford.

Gotelli, N.J., 2002. Ecology - Biodiversity in the scales. Nature 419, 575-576.

Grace, J.B., 1999. The factors controlling species density in herbaceous plant communities, an assessment. Perspectives in Plant Ecology, Evolution, and Systematics 2, 1-28. 
Gray, J.S., 2000. The measurement of marine species diversity, with an application to the benthic fauna of the Norwegian continental shelf. Journal of Experimental Marine Biology and Ecology 250, 23-49.

Griffiths, D., 1997. Local and regional species richness in North American lacustrine fish. Journal of Animal Ecology 66, 49-56.

Guiry, M.D. and Nic Dhonncha, E., 2003. Algaebase. World-wide Web electronic publication. www.algabase.org. [30.12.2003].

Hall, S.J. and Greenstreet, S.P., 1998. Taxonomic distinctness and diversity measures, responses in marine fish communities. Marine Ecology Progress Series 166, 227229.

Hansen, J.W., Udy, J.W., Perry, C.J., Dennison, W.C. and Lomstein, B.A., 2000. Effect of the seagrass Zostera capricorni on sediment microbial processes. Marine Ecology Progress Series 199, 83-96.

Karydis, M. and Tsirtsis, G., 1996. Ecological indices, A biometric approach for assessing eutrophication levels in the marine environment. Science of the Total Environment 186, 209-219.

Knoppers, B., 1994. Aquatic primary production in coastal lagoons. In, Coastal Lagoon Processes ed. Kjerfve, B., p. 243-286, Elsevier Science Publishers, Amsterdam.

Kunii, H. and Minamoto, K., 2000. Temporal and spatial variation in the macrophyte distribution in coastal lagoon Lake Nakaumi and its neighboring waters. Journal of Marine Systems 26, 223-231.

Lydy, M.J., Crawford, C.G. and Frey, J.W., 2000. A comparison of selected diversity, similarity, and biotic indices for detecting changes in benthic-invertebrate community structure and stream quality. Archives of Environmental Contamination and Toxicology 39, 469-479.

Mackey, R.L. and Currie, D.J., 2001. The diversity-disturbance relationship, Is it generally strong and peaked? Ecology 82, 3479-3492.

Magurran, A.E., 1988. Ecological Diversity and its Measurement. Princeton University Press, Princeton.

McRae, G., Camp, D.K., Lyons, W.G. and Dix, T.L., 1998. Relating benthic infaunal community structure to environmental variables in estuaries using nonmetric multidimensional scaling and similarity analysis. Environmental Monitoring and Assessment 51, 233-246.

Mittelbach, G.G., Steiner, C.F., Scheiner, S.M., Gross, K.L., Reynolds, H.L., Waide, R.B., Willig, M.R., Dodson, S.I. and Gough, L., 2001. What is the observed relationship between species richness and productivity? Ecology 82, 2381-2396.

Parker, J.D., Duffy, J.E. and Orth, R.J., 2001. Plant species diversity and composition, experimental effects on marine epifaunal assemblages. Marine Ecology Progress Series 224, 55-67.

Petchey, O.L. and Gaston, K.J., 2002. Functional diversity (FD), species richness and community composition. Ecology Letters 5, 402-411.

Pires, A.M., Cowx, I.G. and Coelho, M.M., 2000. Benthic macroinvertebrate communities of intermittent streams in the middle reaches of the Guadiana Basin (Portugal). Hydrobiologia 435, 167-175.

Plante-Cuny, M.R., Plante, R., Mazouni, N., Fontaine, M.F., Souchu, P., Deslous-Paoli, J.M. and Grenz, C., 1998. Oxygen fluxes involving the benthic micro and macrophytic components in the Thau lagoon under pre-anoxic conditions. Oceanologica Acta 21, 819-829.

Purvis, A. and Hector, A., 2000. Getting the measure of biodiversity. Nature 405, 212-219.

Rice, J.C., 2000. Evaluating fishery impacts using metrics of community structure. Ices Journal of Marine Science 57, 682-688.

Rogers, S.I., Clarke, K.R. and Reynolds, J.D., 1999. The taxonomic distinctness of coastal bottom-dwelling fish communities of the North-east Atlantic. Journal of Animal Ecology 68, 769-782. 
RSL (2001) le bulletin du réseau de suivi lagunaire, résultats sur l'eutrophisation. IFREMER.

Rueness, J., 1989. Sargassum miticum and other introduced Japanese macroalgae, biological pollution of European coasts. Marine Pollution Bulletin 20, 173-176.

Sauriau, P.G., 1991. Spread of Cyclope-Neritea (Mollusca, Gastropoda) Along the NorthEastern Atlantic Coasts in Relation to Oyster Culture and to Climatic Fluctuations. Marine Biology 109, 299-309.

Sfriso, A., Birkemeyer, T. and Ghetti, P.F., 2001. Benthic macrofauna changes in areas of Venice lagoon populated by seagrasses or seaweeds. Marine Environmental Research 52, 323-349.

Shannon, C.E. and Weaver, W., 1949. The Mathematical Theory of Communication. University of Illinois Press, Urbana.

Shimatani, K., 2001. On the measurement of species diversity incorporating species differences. Oikos 93, 135-147.

Simpson, E.H., 1949. Measurement of species diversity. Nature 163, 688.

Somerfield, P.J., Olsgard, F. and Carr, M.R., 1997. A further examination of two new taxonomic distinctness measures. Marine Ecology Progress Series 154, 303-306.

Souchu, P., Vaquer, A., Collos, Y., Landrein, S., Deslous-Paoli, J.M. and Bibent, B., 2001. Influence of shellfish farming activities on the biogeochemical composition of the water column in Thau lagoon. Marine Ecology Progress Series 218, 141-152.

Verlaque, M., 2000. Etangs de Thau et de Salse-Leucate. Actualisation de la flore des macrophytes. GIS Posidonie and IFREMER, PNEC Report, Lagunes Méditerranéennes, 63 p. + Annex. 1-2.

Verlaque, M., 2001. Checklist of the macroalgae of Thau Lagoon (Herault, France), a hot spot of marine species introduction in Europe. Oceanologica Acta 24, 29-49.

Viaroli, P., Bartoli, M., Bondavalli, C., Christian, R.R., Giordani, G. and Naldi, M., 1996. Macrophyte communities and their impact on benthic fluxes of oxygen, sulphide and nutrients in shallow eutrophic environments. Hydrobiologia 329, 105-119.

Waide, R.B., Willig, M.R., Steiner, C.F., Mittelbach, G., Gough, L., Dodson, S.I., Juday, G.P. and Parmenter, R., 1999. The relationship between productivity and species richness. Annual Review of Ecology and Systematics 30, 257-300.

Warwick, R.M., Ashman, C.M., Brown, A.R., Clarke, K.R., Dowell, B., Hart, B., Lewis, R.E., Shillabeer, N., Somerfield, P.J. and Tapp, J.F., 2002. Inter-annual changes in the biodiversity and community structure of the macrobenthos in Tees Bay and the Tees estuary, UK, associated with local and regional environmental events. Marine Ecology Progress Series 234, 1-13.

Warwick, R.M. and Clarke, K.R., 1995. New 'biodiversity' measures reveal a decrease in taxonomic distinctness with increasing stress. Marine Ecology Progress Series 129, 301-305.

Warwick, R.M. and Clarke, K.R., 1998. Taxonomic distinctness and environmental assessment. Journal of Applied Ecology 35, 532-543.

Warwick, R.M. and Clarke, K.R., 2001. Practical measures of marine biodiversity based on relatedness of species. Oceanography and Marine Biology Vol 39 39, 207-231.

Warwick, R.M. and Light, J., 2002. Death assemblages of molluscs on St Martin's Flats, Isles of Scilly, a surrogate for regional biodiversity? Biodiversity and Conservation 11, 99-112.

Weiher, E. and Keddy, P.A., 1999. Relative abundance and evenness patterns along diversity and biomass gradients. Oikos 87, 355-361. 


\section{Appendix}

Taxonomic tree for macrophyte community in Languedoc-Roussillon lagoons (Verlaque

2000, 2001; Guiry \& Nic Dhonncha 2002), exotic species having a star. In the last column, the names of the lagoon where they were sampled: B, M, S and T for respectively, Bages-

Sigean, Mauguio, Salse-Leucate and Thau lagoons

\begin{tabular}{|c|c|c|c|c|c|c|}
\hline Phylum & Class & Order & Family & Genus & Species & Lagoon \\
\hline \multirow{4}{*}{ Magnioliophyta } & \multirow{4}{*}{ Liliopsida } & Najadales & Ruppiaceae & Ruppia & cirrhosa & $\mathrm{S}$ \\
\hline & & \multirow{3}{*}{ Potamogetonales } & Potamogetonaceae & Potamogeton & pectinatus & M \\
\hline & & & \multirow{2}{*}{ Zosteraceae } & \multirow{2}{*}{ Zostera } & marina & BST \\
\hline & & & & & noltii & BST \\
\hline \multirow{2}{*}{ Charophyta } & \multirow{2}{*}{ Charophyceae } & \multirow{2}{*}{ Charales } & \multirow{2}{*}{ Characeae } & Lamprothamnium & papulosum & \multirow[t]{2}{*}{$\mathrm{s}$} \\
\hline & & & & Chara & aspera & \\
\hline \multirow{29}{*}{ Chlorophyta } & & & Bryopsidaceae & Bryopsis & plumosa & $\mathrm{T}$ \\
\hline & & & Chaetosinhonacea & Blastophysa & rhizopus & \\
\hline & & Bryonsidalec & Cnaetosipnonaceae & Chaetosiphon & moniliformis & \\
\hline & & Bryopsidales & Codiaceae & Codium & bursa & \\
\hline & & & Derbesiaceae & Derbesia & fragile $^{*}$ & $\mathrm{~T}$ \\
\hline & & & & Bolbocoleon & $\begin{array}{c}\text { rhizophora } \\
\text { piliferum }\end{array}$ & \\
\hline & & Chaetophorales & Chaetophoraceae & Entocladia & leptochaete & \\
\hline & & Chaetophorales & & Entocladıa & viridis & \\
\hline & & & Chroolepidaceae & Pilinia & sp. & \\
\hline & & & & & aerea & $\mathrm{S}$ \\
\hline & & Cladophorales & Cladophoraceae & Chaetomorpha & $\begin{array}{c}\text { linum } \\
\text { mediterranaa }\end{array}$ & MST \\
\hline & & & & Cladophora & $\frac{\text { mediterranea }}{\mathrm{sp} .}$ & BST \\
\hline & & & & Rhizoclonium & riparium & \\
\hline & Chlorophycea & $\begin{array}{l}\text { Dasycladales } \\
\end{array}$ & $\begin{array}{l}\text { Polyphysaceae } \\
\end{array}$ & Acetabularia & acetabulum & T \\
\hline & & Phaeophilales & Phaeophilaceae & Phaeophila & dendroides & $\mathrm{s}$ \\
\hline & & Siphonocladales & Valoniaceae & Valonia & aegagropila & $\mathrm{s}$ \\
\hline & & Ulotrichales & Ulotrichaceae & Eugomontia & sacculata & \\
\hline & & Ulotrichales & Ulotrichaceae & Ulothrix & sp. & \\
\hline & & & Monostromataceae & Monostroma & obscurum ${ }^{*}$ & $T$ \\
\hline & & & & & $\begin{array}{l}\text { clathrata } \\
\end{array}$ & MT \\
\hline & & & & & compressa & \\
\hline & & & & Enteromorpha & flexuosa & \\
\hline & & & & & intestinalis & \\
\hline & & Ulvales & Ulvaceae & & prolifera & $\mathrm{s}$ \\
\hline & & & & & fasciata $^{*}$ & \\
\hline & & & & Ulva & lactuca & \\
\hline & & & & Ulva & pertusa $^{*}$ & \\
\hline & & & & & rigida & BMT \\
\hline & & & Ulvellaceae & Acrochaete & inflata & \\
\hline & & Cutleriales & Cutleriaceae & Aglaozonia & parvula & \\
\hline & & Cutleriales & Cutleriaceae & Cutleria & multifida & T \\
\hline & & Desmarestiales & Desmarestiaceae & Desmarestia & viridis $^{*}$ & \\
\hline & & & & & dichotoma & T \\
\hline & & Dictyotales & Dictyotaceae & Dictyota & fasciola & \\
\hline & & Dictyotales & & & linearis & \\
\hline & & & & Padina & pavonica & \\
\hline & & & & Acinetospora & crinita & \\
\hline & & & & Feldmannia & sp. & \\
\hline & & & & Streblonema & sp. & \\
\hline & & & & & fuscata & \\
\hline & & & Ectocarnacosa & Hinksia & granulosa & \\
\hline & & Ectocarpales & Ectocarpaceae & & mitchellae & \\
\hline & & & & & $\begin{array}{c}\text { sandriana } \\
\text { fasciculatus }\end{array}$ & \\
\hline & & & & Ectocarpus & siliculosus & \\
\hline & & & & Kuetzingiella & $\mathrm{sp}$. & \\
\hline & & & & Kuckuckia & spinosa & \\
\hline & & & Pylaiellaceae & Pilayella & littoralis ${ }^{*}$ & \\
\hline & & & & & cylindricus & \\
\hline & & & Chordariaceวe & Cladosiphon & mediterraneus & T \\
\hline & & & Choruanaceae & & zosterae $^{*}$ & \\
\hline & & & & Sphaerotrichia & divaricata ${ }^{*}$ & T \\
\hline & & & & Myriactula & sp. & \\
\hline & & & Corynophlaeaceae & Leathesia & difformis $^{*}$ & \\
\hline & & Chordariales & & Cylindrocarpus & microscopicus & \\
\hline & Phaeophyceae & & Acrotrichaceae & Acrothrix & gracilis $^{*}$ & \\
\hline Heterokontophyta & & & Flachistaceae & Elachista & stellaris & \\
\hline Heterokontophyta & & & Elachistaceae & Halothrix & lumbricalis $^{*}$ & \\
\hline & & & Myrionemataceae & Myrionema & orbiculare & \\
\hline & & & Spermatochnaceae & Stilophora & $\begin{array}{l}\text { strangulans } \\
\text { rhizodes }\end{array}$ & \\
\hline & & & Punctariaceae & Punctaria & $\begin{array}{c}\text { rhizodes } \\
\text { latifolia }\end{array}$ & \\
\hline & & Dictyosiphonales & Punctariaceae & Punctaria & tenuissima & \\
\hline & & Dictyosiphonales & Giraudiaceae & Giraudia & sphacelarioides & \\
\hline
\end{tabular}




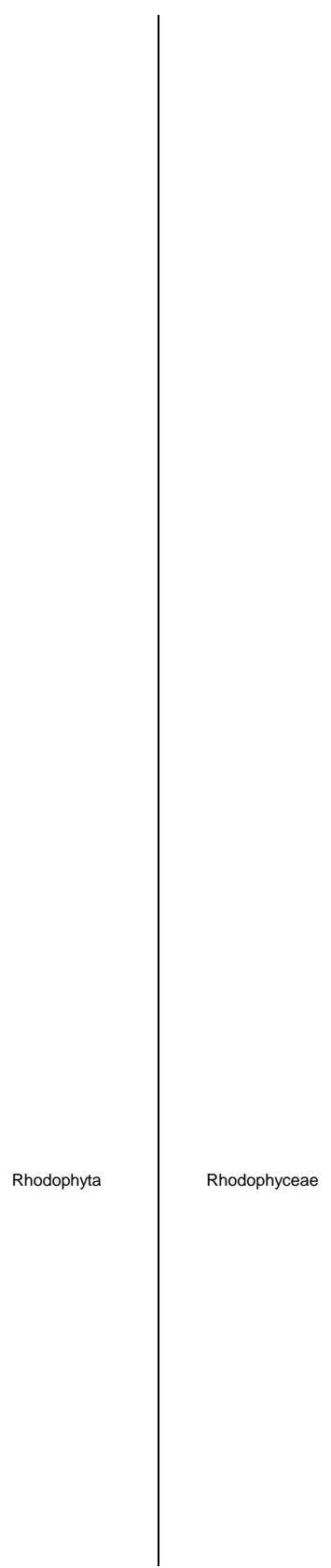

\begin{tabular}{|c|c|c|c|}
\hline \multirow{7}{*}{ Acrochaetiales } & \multirow{7}{*}{ Acrochaetiaceae } & \multirow{7}{*}{ Acrochaetium } & daviesii \\
\hline & & & leptonema \\
\hline & & & mediterraneum \\
\hline & & & reductum \\
\hline & & & savianum \\
\hline & & & secundatum \\
\hline & & & virgatulum \\
\hline \multirow{3}{*}{ Bangiales } & \multirow{3}{*}{ Bangiaceae } & Bangia & atropurpurea \\
\hline & & \multirow{2}{*}{ Porphyra } & leucosticta \\
\hline & & & yezoensis $^{*}$ \\
\hline \multirow{47}{*}{ Ceramiales } & \multirow{18}{*}{ Ceramiaceae } & Aglaothamnion & byssoides \\
\hline & & \multirow{2}{*}{ Antithamnion } & cruciatum \\
\hline & & & nipponicum $^{*}$ \\
\hline & & \multirow{2}{*}{ Callithamnion } & corymbosum \\
\hline & & & tetragonum \\
\hline & & Centroceras & clavulatum \\
\hline & & \multirow{8}{*}{ Ceramium } & ciliatum \\
\hline & & & codii \\
\hline & & & diaphanum \\
\hline & & & $\frac{\text { flaccidum }}{\text { petitii }}$ \\
\hline & & & secundatum \\
\hline & & & siliquosum \\
\hline & & & strictum \\
\hline & & & tenerrimum \\
\hline & & Griffithsia & corallinoides $^{*}$ \\
\hline & & Pterothamnion & plumula \\
\hline & & Seirospora & giraudyi \\
\hline & & Spyridia & filamentosa \\
\hline & \multirow{2}{*}{ Dasyaceae } & Dasya & sessilis $^{*}$ \\
\hline & & Dasysiphonia & sp.* \\
\hline & \multirow{3}{*}{ Delesseriaceae } & Acrosorium & venulosum \\
\hline & & Nitophyllum & punctatum \\
\hline & & Radicilingua & $\begin{array}{c}\text { reptans } \\
\end{array}$ \\
\hline & & Alsidium & corallinum \\
\hline & & & capillaris \\
\hline & & Chondria & coerulescens ${ }^{*}$ \\
\hline & & & dasyphylla \\
\hline & & Halopithys & incurva \\
\hline & & Herposiphonia & parca ${ }^{*}$ \\
\hline & & Laurencia & microcladia \\
\hline & & & okamurae $^{*}$ \\
\hline & & Lophosiphonia & obscura \\
\hline & & Osmundea & truncata \\
\hline & & & atlantica \\
\hline & & & brodiei \\
\hline & Rhodomelaceae & & denudata \\
\hline & & & elongata \\
\hline & & & furcellata \\
\hline & & Polvsiphonia & harveyi* \\
\hline & & Polysipnonia & morrowiit \\
\hline & & & opaca \\
\hline & & & paniculata $^{*}$ \\
\hline & & & sertularioides \\
\hline & & & setigera \\
\hline & & & subulata \\
\hline & & Pterosiphonia & pennata \\
\hline & & & tanakae ${ }^{*}$ \\
\hline & & Rytiphloea & tinctoria \\
\hline & & Corallina & elongata \\
\hline & & Hydrolithon & farinosum \\
\hline & & Lithophyllum & yessoense ${ }^{*}$ \\
\hline Corallinales & Corallinaceae & Lithothamnion & sp. \\
\hline & & Phymatolithon & lenormandii \\
\hline & & Pneonbyllum & confervicola \\
\hline & & Pneophyllum & fragile \\
\hline & & Titanoderma & pustulatum \\
\hline & & & carnea \\
\hline Erythropeltidales & Erythropeltidaceae & Erythrotrichia & investiens \\
\hline & & Sahlingia & subintegra \\
\hline
\end{tabular}

